TITLE:

\title{
ELECTRON MICROSCOPY ON A GORGONIAN CORAL, ANTHOPLEXAURA DIMORPHA
}

$\operatorname{AUTHOR}(\mathrm{S})$ :

Kawaguti, Siro; Kamishima, Yoshihisa

\section{CITATION:}

Kawaguti, Siro ... [et al]. ELECTRON MICROSCOPY ON A GORGONIAN CORAL, ANTHOPLEXAURA DIMORPHA. PUBLICATIONS OF THE SETO MARINE BIOLOGICAL LABORATORY 1973, 20: 785-793

ISSUE DATE:

1973-12-19

URL:

http://hdl.handle.net/2433/175742

RIGHT: 


\title{
ELECTRON MICROSCOPY ON A GORGONIAN CORAL, ANTHOPLEXAURA DIMORPHA
}

\author{
SIRo KAWAGUTI and YoshIHISA KAMISHIMA \\ Department of Biology, Faculty of Science, Okayama University \\ Okayama, Japan
}

With 11 Text-figures

\begin{abstract}
Gorgonian corals usually have arboreal colonies with many slender stems and branches. Each of these stems or branches is composed of a horny axis and of an outer cover of living portion with numerous calcareous spicules. In a previous paper covering a gorgonian, Euplexaura erecta, we have described only the spicules but not the horny axis (2). In the present work both spicules and the axis have been observed in the same section under an electron microscope. The axis of the tip portion of a branch is much thinner than that in the previous species. The axis shows a characteristic structure with longitudinal arrangements of bundles of keratinous fibrils which are derived from fibroblasts on the axis surface. The process of spicule formation is somewhat different from that in the previous species.
\end{abstract}

\section{Material and Methods}

A gorgonian coral, Anthoplexaura dimorpha KüKENTHAL, was used as the material in this experiment. It was collected in the vicinity of the Tamano Marine Laboratory in 1964 and 1970. It forms a small colony with slender branches of various length. The branch is constituted of an axial skeleton of horny substance and a thick covering of living portion. The living portion is further composed of many polyps (anthozooid) and coenosarcs (coenenchyme) with numerous small calcareous spicules. The axis is thin, especially at its distal portion, giving the branches great flexibility. The axis is a dark chocolate brown. The polyps are light orange in color, but the coenosarcs are deep red with many spicules of the same color.

Apical portions from several branches were cut from a living colony and put into $6 \%$ ice-cold glutaraldehyde buffered with $0.1 \mathrm{M}$ cacodylate and with $0.2 \mathrm{M}$ sucrose, $\mathrm{pH}$ adjusted to 7.2. After 1.5 hour's prefixation in the above solution, tissue blocks were rinsed with a buffer solution. They were post-fixed in a $1 \%$ osmium tetroxide solution buffered at $\mathrm{pH} 7.2$ with $0.1 \mathrm{M}$ cacodylate for two hours. Then, they were rinsed in the buffered solution three times and were dehydrated through a series of graded ethanol and propylene oxide. They were embedded in Epon 812. Thin 
sections were cut on a glass knife with an IVAN-Sovall MT-1 type ultramicrotome or an LKB ultrotome.

For decalcification, tissues embedded in resin were exposed by cutting and immersed in EGTA solution for two days. Thin sections were stained with lead citrate or double-stained with saturated uranyl acetate and lead citrate and examined under a Hitachi HU-11E type electron microscope. Some sections obtained from nondecalcified blocks were examined before staining to observe the original sites of calcium deposition. Thick sections were also cut from electron microscope preparations and stained with toluidine blue for ordinary light microscopic survey.

\section{Results}

\section{A. Light Microscope Observations}

Fig. 1 shows a cross section through an apical portion of a branch of Anthoplexaura dimorpha. The outer surface of the branch is covered with a very thin ectoderm of a single cell layer. Under the ectoderm there is a thick layer of mesogloea which contains many spicules and mesogloeal cells various in form and dimension. The other side of the mesogloea, that is, the wall of the gastrovascular system, is lined with an endoderm of tall cells. The endoderm is especially thick at the mesenteries and it sometimes contains eggs and sperms as is seen in the lower portion of the picture. The innermost concentric figure is a cross section of an axis.

The outer surface of the axis faces a continuous layer of dark cells. These cells are of ectodermal origin and are responsible for the formation of the axis. The outer side of these cells is continuous with the mesogloea where a few spicules are also found.

\section{B. Electron Microscope Observations}

a. Ectodermal and endodermal cells

The outer surface of the body is covered with a single layer of ectodermal cells. Each of these cells is very thin and measures only a few micra in thickness, frequently less than $0.5 \mu$. It has an elongated nucleus and complicated cytoplsm with many dark spheroids, endoplasmic reticula and vesicles of various dimensions. It is provided with long microvilli on the outer surface and a basal lamina on the inner side facing the underlying mesogloea. It is connected with the neighbouring cells by means of desmosomes and indentations.

Under a thin covering of the ectodermal cells there is a very thick mesogloea which contains many mesogloeal cells, scleroblasts and spicules. Fig. 2. is a part of the surface area of the coenosarc showing the ectodermal cover on the upper surface and a group of mesogloeal cells. These cells show irregular forms with many extensions and have a complicated cytoplasm loaded with many dark spheroids, endoplasmic reticula and vesicles of various dimensions. These characteristics of the mesogloeal cells are closely similar to those of the ectodermal cells. But, the meso- 


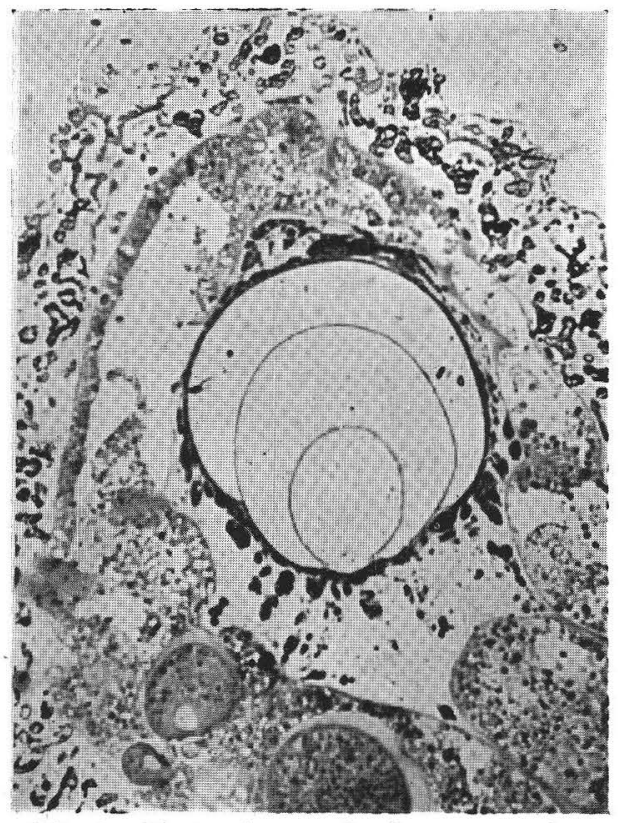

Fig. 1. Photomicrograph of a cross section through an apical portion of a branch of Anthoplexaura dimorpha.

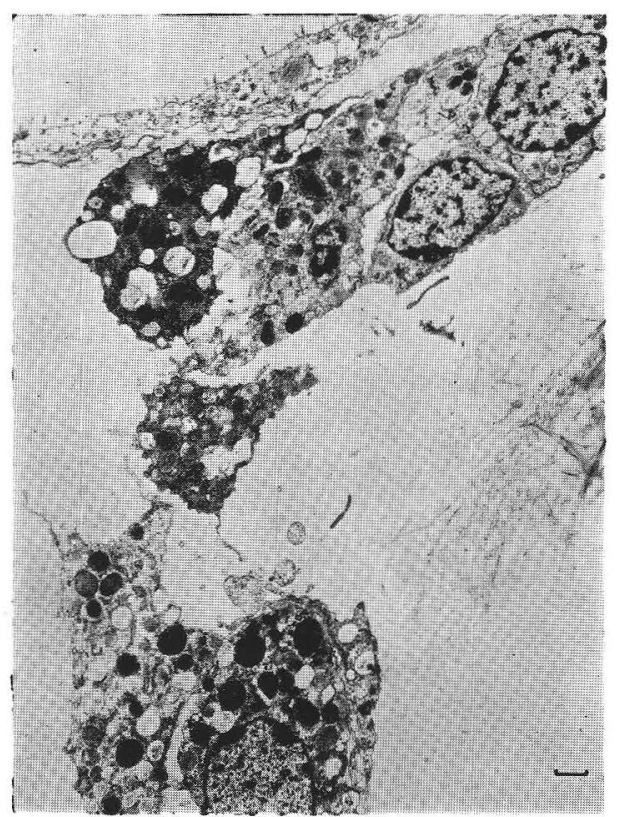

Fig. 3. Electron micrograph of a group of mesogloeal cells near the ectodermal layer.

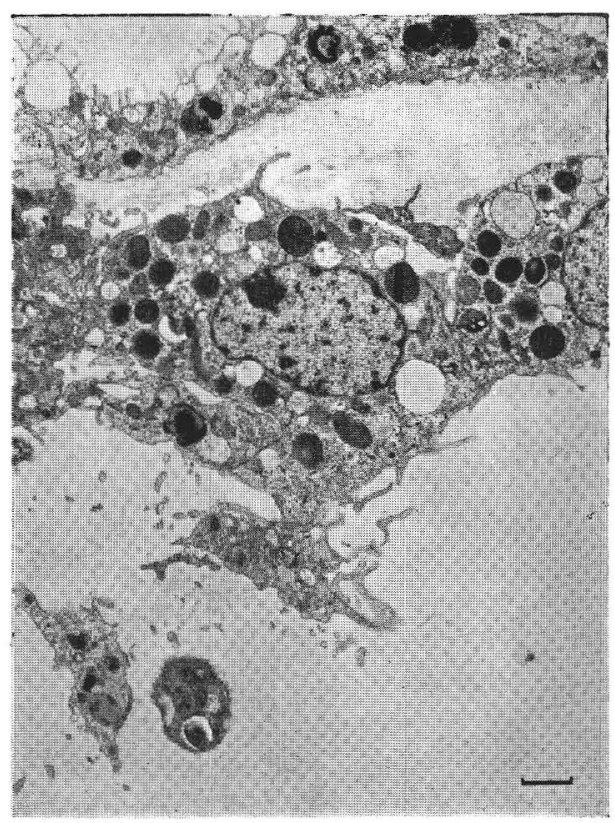

Fig. 2. Electron micrograph of an outer portion of the coenosarc of Anthoplexaura dimorpha showing ectodermal and mesogloeal cells. The scale in electron micrographs indicates $1 \mu$, except in Fig. 7 .

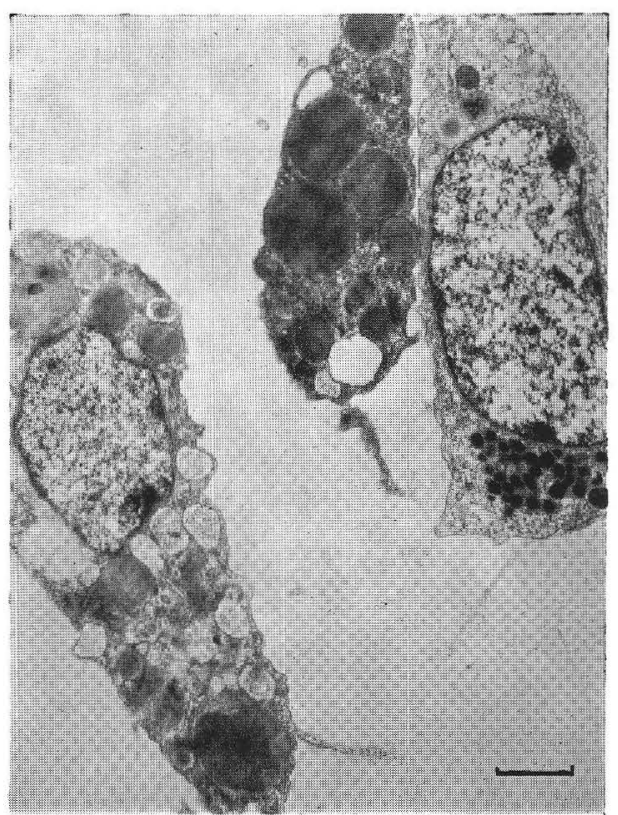

Fig. 4. Enlarged view of three mesogloeal cells showing two types of cytoplasm. 


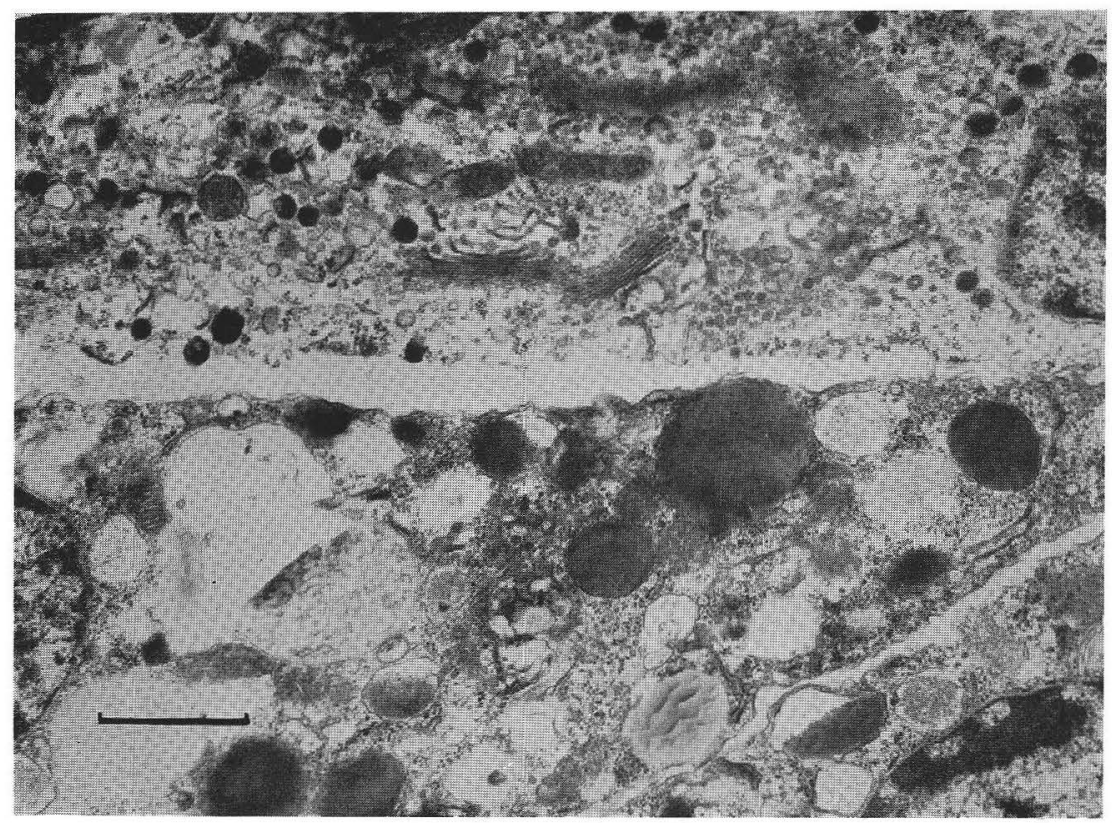

Fig. 5. Further enlargement of parts of two mesogoeal cells showing details of cytoplasmic inclusion.

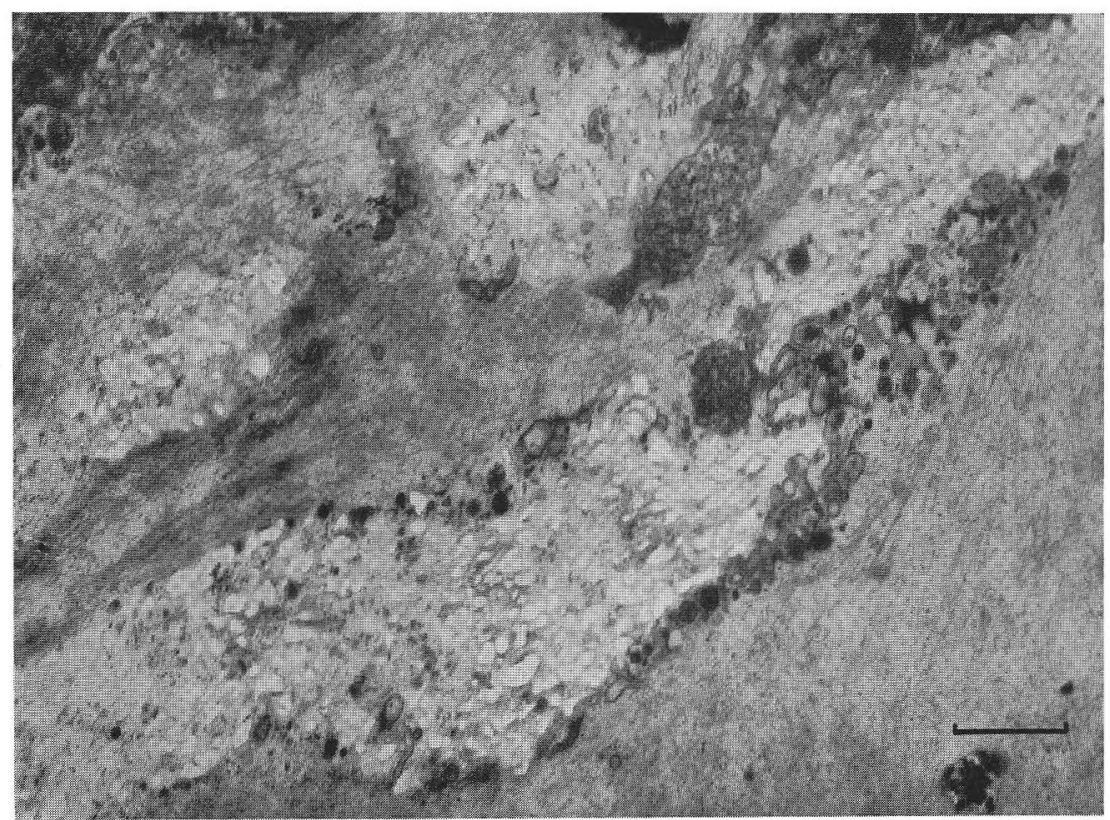

Fig. 6. Young scleroblasts at a growing surface of a spicule in the mesogloea. 


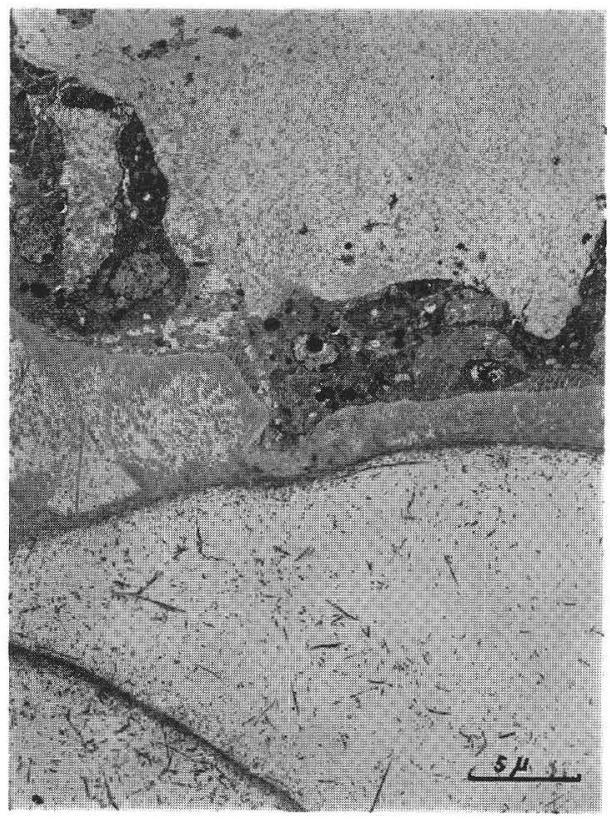

Fig. 7. A part of the surface region of the axis covered with epithelial cells.

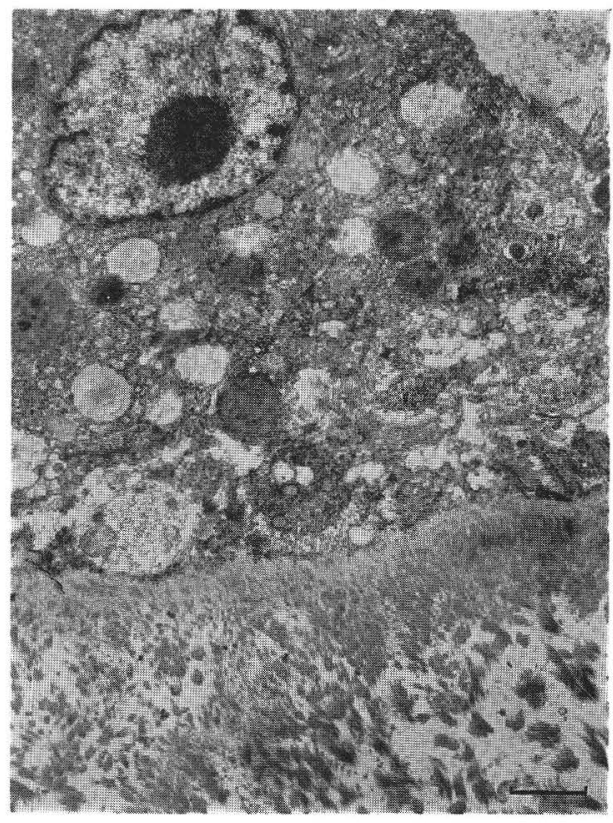

Fig. 8. Enlarged view of a part of an axis epithelial cell with underlying axis.

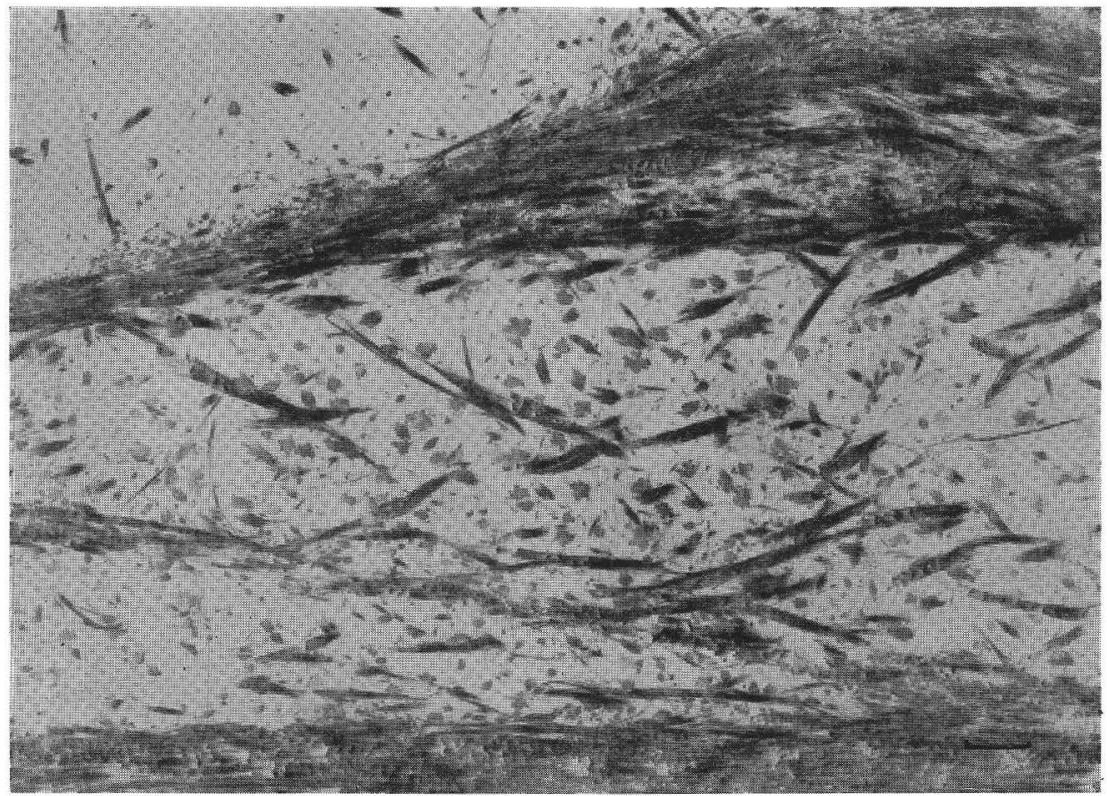

Fig. 9. Enlarged view of a part of axis showing details of fibril arrangements. 


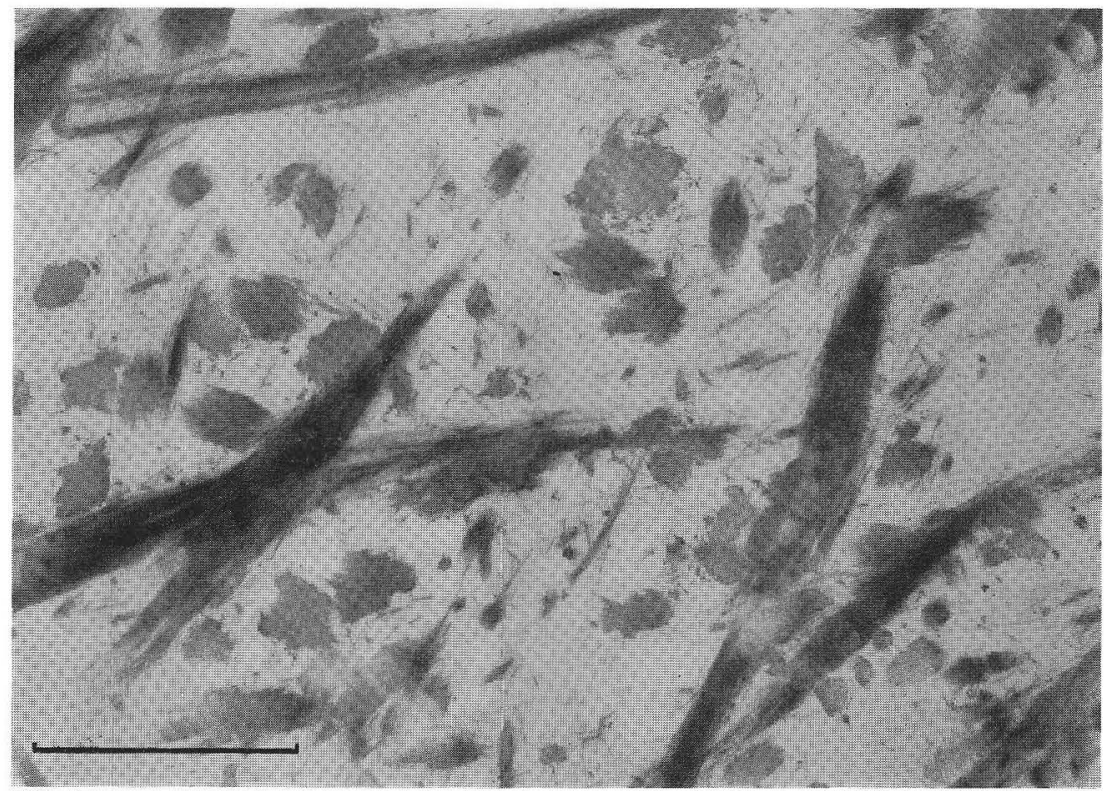

Fig. 10. Further enlarged picure of a part of the axis showing details of organizations of fibrils.

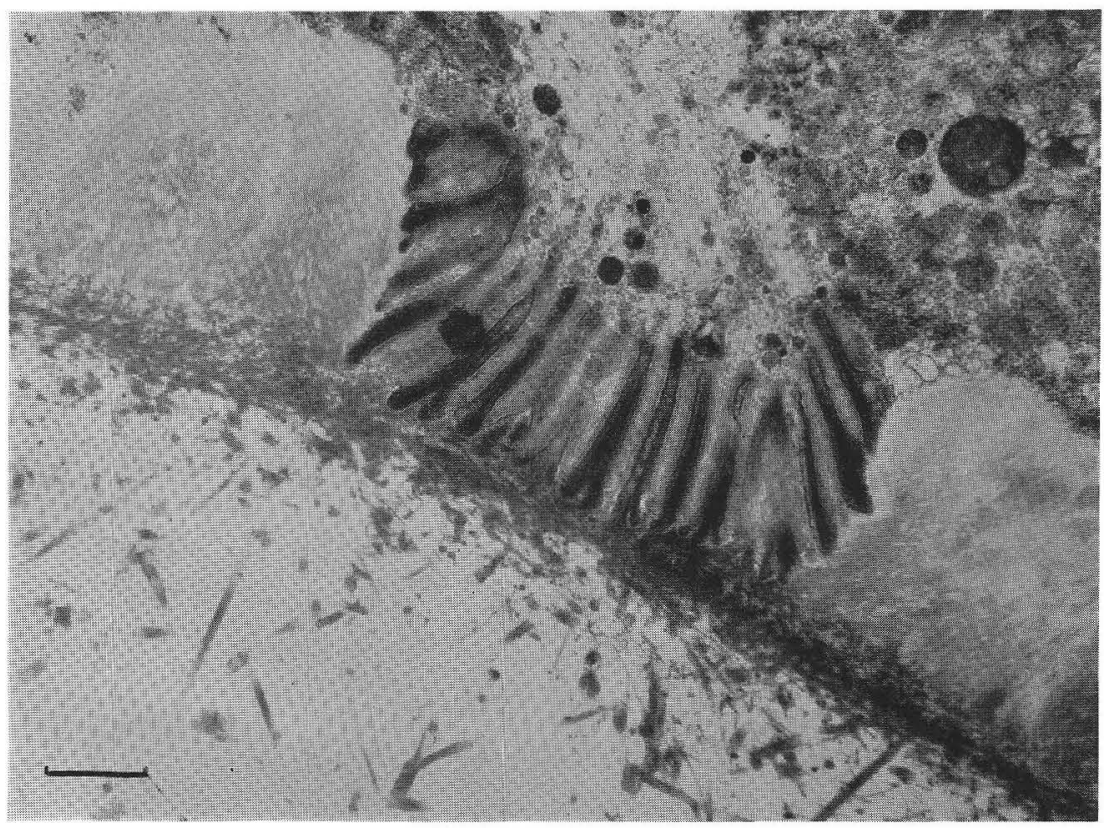

Fig. 11 Enlarged view of an attachment of the epithelial cell to the axis. The main portion of the attachment remains on the surface of an old ring. 
gloeal cells are found separated from each other or in a small group usually having several filamentous extensions or pseudopodia on the surface. In some cases they are found in close association with ectodermal cells, suggesting the origin of the mesogloeal cells.

The endodermal or gastrodermal cells that form a vascular wall are tall and cuboidal. They are uniform in size and are quite different from those of the ectoderm. They contain numerous digestive granules and mucus particles. In their basal portions thin muscle fibers are usually observed.

b. Mesogloeal cells and scleroblasts

Young mesogloeal cells are usually found near the ectoderm. They gradually migrate into the mesogloea as is shown in Fig. 3, and soon differentiate into two types in their cytoplasmic features. The first type contains many spherical bodies, or pigment granules. We may call this a pigment cell (Fig. 4). The second type, the vesiculated cell, has no pigment granules but many small vesicles and well developed Golgi bodies. The first type is more abundant than the second. Further details of cytoplasmic inclusions in these two types of cells are shown in Fig. 5. Vesicles in the vesiculated cell are various in size ranging from $50 \mu \mu$ to $250 \mu \mu$ in diameter. They contain materials of varying density and some appear almost empty. There are some indications that these vesicles are formed from Golgi bodies.

Smaller vesicles have opaque contents and appear to have just become detached from Golgi bodies. They frequently come in contact with one or more neighbouring vesicles to form a larger vesicle of lower density. Vesicles of high density are irregular in shape, while the others are more or less spherical.

Fig. 5 shows details of cytoplasmic inclusions in the two kinds of mesogloeal cells. The lower one is a pigment cell containing large pigment granules of light and heavy densities. The upper one is a vesiculated cell which is rich in Golgi bodies and endoplasmic reticula.

The second type of mesogloeal cell, the vesiculated cell, seems to turn gradually into a young scleroblast. The scleroblast soon undergoes calcification and settles on a spicule resulting in irregular warts on its surface. In the coenosarc it is somewhat difficult to follow the process of calcification in scleroblasts because of the great accumulation of spicules.

Fig. 6 shows parts of young scleroblasts at a growing surface of a spicule in the mesogloea. Each scleroblast is composed of a central clear area and a peripheral cellular portion. Outer boundaries of the peripheral portion are not clearly defined but membrane fragments are observed here and there. However, no mesogloea filament is found within these areas.

The central area is a dense distribution of empty vesicles of various dimensions in a homogeneous matrix. Empty vesicles are the remains of decalcified particles. In and around this area there are some dense vesicles which are precursors of calcified 
particles. The peripheral portion is observed as an accumulation of particles and vesicles or as a single covering of them. Similar pictures of the scleroblast are observed in Tubipora musica (5) and in Heteroxenia elisabethae (4) which has typical unicellular spicules (1).

c. The axis and its epithelium

The surface of the axis is covered with a layer of axis epithelial cells (Fig. 7). These cells are closely attached to the axis with a rather smooth contact surface. Here and there elaborate attachment structures are found on the surface. The cells appear very dark with many dark vesicles of various dimensions, endoplasmic reticula and Golgi bodies, indicating a very active formation of fibril substances. Further details are shown in an enlarged picture (Fig. 8).

The axis is seen as a concentric figure with alternate arrangements of a wide white ring and a thin dark ring. The white ring is composed of a diffuse distribution of small fibrils, while the dark one is constituted of compact arrays of similar fibrils. The actual distribution of fibrils differs from portion to portion. The main arrays of fibrils are found arranged longitudinally along the axis. However, some of them run in various directions (Fig. 9). Each of these fibrils tapers at both ends and measures $0.2 \mu$ in diameter at the middle thickest portion. It frequently sends thin branches especially near its ends and shows an anastomosing figure under a high magnification (Fig. 10). It is further composed of bundles of fine filaments of 20-30 $\AA$ in diameter. No other structures than these fibrils are detectable in the axis.

The peripheral region or the outer ring of the axis which faces the epithelium is somewhat different from those of the inner region. It is composed of a thick layer of a compact load of fibrils of medium density (Figs. 7 and 11). Sometimes it shows an intermediate form between this structure and that of the inner ring. This indicates the process of formation of the axis from the axis epithelium cell.

An attahment structure is enlarged in Fig. 11. The main portion of this structure is settled on an old ring of the axis as a projection into the new periphreal region. The dark bars standing vertically to the axis are extensions of the epithelial cell into the underlying mesogloea which shows corresponding invaginations. At the contact surface to the axis, the epithelial cell forms a very thin cover. That is, this attachment structure is a complicated chain of half desmosomes. The axis is firmly attached to the living portion. Similar attachment structures are observed in a hydrozoa (3), reef corals (6) and an organ-pipe coral (5).

\section{Summary}

1. Spicules and the axis of a gorgonian, Anthoplexaura dimorpha, were observed under an electron microscope.

2. Spicules are composed of depositions of many scleroblasts and pigment cells 
of ectodermal origin.

3. The axis is composed of several concentric rings and encircled by the axis epithelium. Each ring is further constituted of dense and diffuse distributions of many fibrils which are produced by the epithelial cell.

\section{REFERENCES}

1. Hyman, L. H., 1941. The invertebrates I. 538-566. McGraw-Hill, New York.

2. KawaGuti, S., 1964. Electron microscopy on the spicules and polyp of a gorgonian, Euplexaura erecta. Biol. J. Okayama Univ 10, 23-38.

3. 1 1966. Electron microscopy on the Hydrozoa, Orthopyxis caliculata. Ibid., 12, 93-106.

4. - 1969. Electron microscopy on a soft coral, Heteroxenia elisabethae KöLLIKER. Ibid., 15, 25-35.

5. - (unpublished).

6. WISE, S. W., 1970. Scleractinian coral exoskeleton: surface microarchitecture and attachment scar patterns. Science, 169, 978-980.

\section{DISCUSSION}

YAMAZATo: What would you think of the role of pigmented cells in calcification?

Kamishima: I think those pigmented cells are responsible for the coloration of the spicule, while vesiculated cells seem to be the sites where calcium salts deposit.

SATo: Would you have any direct data prooving the actual calcification site in the active mesogloea cell?

Kamishima: No, I haven't had any direct evidences so far. I think, however, my conclusion agrees with Dr. KAWAGUTI's work on Euplexaura, in which he showed intracellular formation of spicules.

MACKIE: Do you see any organic material in the vesicles of the vesiculated cells?

KAMISHima: I think that those dense materials seen in vesicles are of organic nature onto which calcium begins to precipitate.

ChAPMAN: Your proposed scheme for calcification involves an electron dense uncalcified vesicle which subsequently becomes calcified; however, in your decalcified specimens, the calcified vesicles are empty and the precalcified dark vesicles are intact. What then, happened to the electron dense material in the calcified vesicles?

Kamishima: I think the dense material has been removed during the decalcification. When calcium salts are dissolved away, there may occur some mechanical disturbance in the calcified vesicles, and this will cause materials in these vesicles, including the dense one, ready to be easily removed. In the case of pre-calcified vesicles, in which calcium salts have not yet been precipitated, the decalcification will not cause any disturbances in the vesicles, and the dense material remains intact.

KAWAGUTI: Some additional pictures to show more clearly the process of calcification in calicoblast are seen for the case of Heteroxenia. 